\title{
Uplatňovanie kasačného princípu pri preskúmavaní rozhodnutí správnych orgánov (inauguračná prednáška)
}

\author{
Vačok,J.*
}

VAČOK, J.: Uplatňovanie kasačného princípu pri preskúmavaní rozhodnutí správnych orgánov (inauguračná prednáška). Právny obzor, 104, 2021, č. 2, s. 89 - 98.

\begin{abstract}
The Application of Principle of Cassation in the Examination of Decisions of Administrative Authorities (Inauguration Lecture). The author summarizes his research relating to the system of remedies against administrative authorities' decisions. He points out the broad spectrum of them, including appeal, action to the court, cassation complaint, a complaint to the Constitutional Court of the Slovak Republic, and complaint to the European Court of Human Rights. The author also notices on the other measures of reviewing administrative decisions. These are examining outside the appellate procedure, retrial, and supervision by the prosecution. Under the opinion of the author, the comprehensive system of remedies is not necessary the advantage. It could try to ensure better control, but on the other side it could interfere with the principle of legal certainty The author mainly points out the interferences in legal certainty. One of the reasons is that most of the remedies direct against the decisions in force. The second is that a large part of the higher instance authorities decides by the principle of cassation. These elements allow open the finished proceedings and prolong the total length of the whole procedures. According to the analysis of the particular remedies in the whole system, the author offers proposals to the future. He gives his attention to the pros and cons of principles for decision (especially to the appellate principle and principle of cassation). He points out the possibility of reducing some instances. He also states the conditions under which the current system could remain. Finally, the author points out the impact of the current system of remedies on public credibility.
\end{abstract}

Key words: remedies, review procedure, decision of the administrative body

Milé dámy, vážení páni,

pri zvažovaní témy mojej inauguračnej prednášky som sa snažil zvolit' si tému, ktorá by čo najviac vystihovala moje pôsobenie na poli právnej teórie, ale aj akademickej praxe. Záujem o problematiku správneho procesu a prostriedkov kontroly správnosti a zákonnosti správnych aktov sa začal v rámci doktorandského štúdia, v ktorom som sa venoval problematike správneho súdnictva. Po doktorandskom štúdiu som vo svojom vý-

* Doc. JUDr. Juraj V a č o k, PhD., Katedra správneho a environmentálneho práva, Právnická fakulta UK, Bratislava. 
skume pokračoval, pričom som záujem rozšíril na celé správne konanie. Dôkazom je aj členstvo v dvoch grantoch Agentúry na podporu výskumu a vývoja, ktorých výskumné úlohy boli úzko späté so správnym konaním a súdnym prieskumom správnych aktov. V tejto vedeckej činnosti pokračujem aj v súčasnosti. Svoje nosné aktivity realizujem v rámci projektu VEGA s názvom Prieskum právoplatných individuálnych správnych aktov v kontexte právnej istoty a spravodlivosti vedeného pod číslom 1/0686/18.

$\mathrm{V}$ prednáške preto poukážem na niektoré z nosných problémov, ktorým sa venujem vo svojom výskume, a predstavím aj možnosti, akými sa budem uberat' pri ich d’alšom riešení. Táto prednáška bude tak určitou syntézou poznatkov nadobudnutých v mojej doterajšej práci.

Bolo by nespravodlivé tvrdit', že všetko sú to len moje poznatky. Moja činnost' by nemohla existovat' bez kvalitnej vedeckej spolupráce doma i v zahraničí a dobre postavených vedeckých tímov. Takisto vel'ký význam má pre mňa aj spolupráca s praxou, bez ktorej si svoj výskum viem len vel'mi t’ažko predstavit'.

Svoju prednášku som zameral na uplatňovanie kasačného princípu pri preskúmavaní rozhodnutí správnych orgánov. V rámci nej budem vychádzat' najmä so všeobecnej právnej úpravy nachádzajúcej sa v právnom predpise číslo 460/1992 Zb. Ústava Slovenskej republiky v znení neskorších zmien (d’alej len Ústava), v Dohovore o ochrane l'udských práv a základných slobôd (d’alej len Dohovor), v zákone číslo 71/1967 Zb. o správnom konaní (správny poriadok) v znení neskorších zmien (d’alej len správny poriadok) a v zákone číslo 162/2015 Z. z. Správny súdny poriadok v znení neskorších zmien (d’alej len Správny súdny poriadok).

V prednáške sa budem venovat' jednotlivým prostriedkom nápravy pri preskúmaní správnych rozhodnutí, princípom uplatňujúcim sa pri rozhodovaní a výhodám i nevýhodám súčasného nastavenia. Posudzovanie kvality budem realizovat' aj s ohl'adom na časové hl'adisko. V závere navrhnem možné spôsoby, akými by bolo možné sa d'alej uberat' pri riešení problémov prezentovaných $\mathrm{v}$ rámci prednášky.

\section{Systém prostriedkov nápravy nezákonnosti a nesprávnosti rozhodnutí správnych orgánov}

Zastávam názor, že žiadne právne odvetvie nemá tak rozsiahly systém prostriedkov nápravy nezákonnosti a nesprávnosti ako správne právo. Samotné správne konanie je historicky budované na princípe dvojstupňovosti konania. Následne nadväzuje možnost' preskúmat' správne rozhodnutia v rámci správneho súdnictva. To síce podl’a súčasnej právnej úprave je jednostupňové, ale väčšinu rozhodnutí správnych súdov je možné preskúmat' $\mathrm{v}$ rámci konania o kasačnej st'ažnosti. $\mathrm{V}$ d’alšom postupe prichádza do úvahy obrátit' sa na Ústavný súd Slovenskej republiky so st’ažnost’ou podl’a článku 127 Ústavy. Celý proces je možné zakončit' st'ažnost’ou na Európsky súd pre l'udské práva podl'a článku 34 Dohovoru.

Uplatnenie jednotlivých prostriedkov nápravy je viazané na zákonné podmienky. Tieto podmienky sú však nastavené tak široko, že jednotlivé prostriedky možno využit' podl'a môjho názoru takmer vo všetkých prípadoch. 
V správnom konaní je rozhodnutie správneho orgánu preskúmatel'né na základe odvolania, ktoré je možné podl'a $§ 53$ správneho poriadku podat' vždy, ak osobitný zákon neustanovuje inak. Obdobnú úpravu nachádzame aj pri žalobe na správny súd. Podl'a článku 46 odseku (2) Ústavy je možné podat’ žalobu voči rozhodnutiu správneho orgánu vždy, ak takéto právo nie je vylúčené právnym predpisom so silou zákona.

Na podanie kasačnej st'ažnosti sú taxatívne stanovené dôvody. Pretože sa v správnom súdnictve primárne kontroluje zákonnost', je podl’a môjho názoru možné každú kasačnú st'ažnost' opriet' o dôvod uvedený v § 440 odseku (1) písmene g) Správneho súdneho poriadku. Podl'a tohto ustanovenia možno odôvodnit' kasačnú st’ažnost' tým, že správny súd rozhodol na základe nesprávneho právneho posúdenia veci.

Podanie ústavnej st’ažnosti je naviazané na namietanie poručenia základných práv alebo slobôd. Napriek tejto podmienke sa domnievam, že každé jedno porušenie subjektívneho práva má svoj vplyv na niektoré zo základných práv a slobôd. $Z$ tohto dôvodu si myslím, že možnost' podat' ústavnú st'ažnost' je pomerne široká.

Obdobne je to aj pri st’ažnosti na Európsky súd pre l'udské práva, ktorú je možné podat' za predpokladu porušenia práv priznaných Dohovorom alebo niektorým z protokolov. Napriek skutočnosti, že sa Dohovor nevzt'ahuje na všetky správne konania, domnievam sa, že jeho pôsobnost' je aj tak široká.

Ak zrátame správne konania a uvedené prostriedky nápravy, vzniká nám pomyselných šest' stupňov, v ktorých rámci je možné predmetnú vec prejednat' a skontrolovat'. Navyše, okrem toho je možné správne rozhodnutia preskúmat’ aj inými prostriedkami, medzi ktoré možno zaradit' mimoriadne opravné prostriedky ${ }^{1}$ a d’alšie prostriedky realizované subjektmi externej kontroly. ${ }^{2}$

\section{Charakter prostriedkov nápravy}

Ak by som chcel expresívne vyjadrit' proces preskúmavania rozhodnutí správnych orgánov, označil by som ho za boj so spravodlivost'ou a časom. S ohl'adom na počet prostriedkov nápravy by sa mohlo zdat', že je garantovaná skutočne vel'ká kontrola dodržania zákonnosti. Táto kontrola však naráža najmä na systémové a časové limity.

Po posúdení charakteru jednotlivých prostriedkov nápravy je treba uviest', že pri nich prevažuje primárne kasačný princíp. ${ }^{3}$ Výnimkou je odvolanie, ktoré je primárne budované na apelačnom princípe. ${ }^{4}$ Pri ostatných prostriedkoch nápravy kasačný princíp vyjadruje, že konanie o týchto prostriedkoch nie je pokračovaním správneho kona-

${ }^{1}$ Podl'a správneho poriadku možno za mimoriadne opravné prostriedky považovat' obnovu konania a preskúmanie rozhodnutia mimo odvolacieho konania.

${ }^{2}$ Príkladom je prieskum prokurátora v rámci výkonu všeobecného dozoru podl’a $§ 21$ odseku (1) písmena a) bodu 1. zákona číslo 153/2001 Z. z. o prokuratúre v znení neskorších zmien a prieskum verejným ochrancom práv podl’a článku 151a odseku (1) Ústavy v spojení s $§ 3$ zákona číslo 564/2001 Z. z. o verejnom ochrancovi práv v znení neskorších zmien.

${ }^{3} \mathrm{~K}$ jednotlivým princípom pre rozhodnutie pozri bližšie SOBIHARD, J. Správny poriadok. Komentár. Bratislava : Iura Edition, 2011, s. 234-235.

${ }^{4} \mathrm{~K}$ tomu pozri najmä $§ 59$ správneho poriadku. 
nia a subjekty oprávnené viest' tieto konania sa nachádzajú v pozícii subjektov vonkajšej kontroly. ${ }^{5}$

Zrejmá aplikácia kasačného princípu je v konaniach pred správnym súdom a kasačným súdom. ${ }^{6} \mathrm{~V}$ určitých situáciách však Správny súdny poriadok pripúšt’a aj aplikáciu apelačného princípu. ${ }^{7}$

Charakter konania o ústavnej st'ažnosti tiež vykazuje znaky kasačného princípu. V súlade s článkom 127 odsekom (2) Ústavy Ústavný súd Slovenskej republiky v prípade porušenia rozhodnutím verejnomocenskej autority môže len deklarovat' porušenie práv a zrušit' napadnuté rozhodnutie. Znamená to, že v rozhodovacích procesoch nemôže svojím rozhodnutím (nálezom) napravit' už existujúce protiústavnost' a nezákonnost'.

Obdobná situácia je pred Európskym súdom pre l’udské práva. Európsky súd pre l'udské práva spravidla len skonštatuje porušenie Dohovoru a prípadne prizná primerané zadost'učinenie, ktoré však nemá charakter náhrady škody. Charakter rozhodovania tohto nemožno podradit' síce pod kasačný princíp. Dôležité je však, že Európsky súd pre l'udské práva tiež nemôže priamo napravit' situáciu tak, že zmení rozhodnutie vnútroštátneho súdu alebo správneho orgánu v správnom konaní.

Predmetná koncepcia vytvára situácie, v ktorých sa subjekty právnych vzt'ahov dostávajú do právnej neistoty. Dôvodom je, že v rámci správneho súdnictva, tak aj ústavného súdnictva i Európskeho súdu pre l'udské práva, sú preskúmavané rozhodnutia, ktoré sú z formálneho hl'adiska považované za konečné. Znamená to, že dochádza $\mathrm{k}$ rušeniu rozhodnutí, ktoré už v právnej praxi mohli spôsobovat' právne účinky. Zásah do takéhoto právneho stavu je spojený s výrazným zásahom do princípu právnej istoty.

Uvedené treba posudzovat' tiež $\mathrm{v}$ časových rámcoch, $\mathrm{v}$ ktorých sa prejednávajú jednotlivé opravné prostriedky. Pri prostriedkoch nápravy, ktorými je možné zasiahnut' do právoplatného právneho stavu, totiž čas zohráva vel'mi negatívnu úlohu.

Pomerne prísne lehoty sú stanovené na rozhodovanie v správnom konaní. Podla $§ 49$ by mal správny orgán rozhodovat’ bezodkladne. Za univerzálnu lehotu pre rozhodnutie pritom možno označit' 30-dňovú lehotu, z ktorej budem v d'alšom texte vychádzat'.

Prísne lehoty sú stanovené aj pre odvolacie konanie. Ak správny orgán v tomto konaní autoremedúrne nerozhodne, je povinný podla $§ 57$ odseku (2) správneho poriadku predložit' odvolanie spolu so spisovným materiálom odvolaciemu orgánu. S ohl'adom na § 60a správneho poriadku možno všeobecnú lehotu odvolacieho orgánu ustálit’ na 30 dní.

Správne súdy, kasačný súd, Ústavný súd Slovenskej republiky a ani Európsky súd pre l'udské práva nemajú stanovené lehoty na rozhodnutie. Pri posudzovaní dížky procesov na týchto súdoch možno vychádzat' zo štatistických informácií o reálnej dížke konaní. Na účely tejto prednášky budem vychádzat' najmä zo štatistických údajov za

${ }^{5}$ Súdna kontrola verejnej správy je považovaná za jeden z druhov vonkajšej kontroly verejnej správy. Bližšie k tomu pozri napríklad PEKÁR, B. Kontrola vo verejnej správe v kontexte Európskeho správneho súdnictva. Bratislava : Univerzita Komenského v Bratislave, Právnická fakulta, 2011, s. 95.

${ }^{6}$ Pozri k tomu $§ 191$ odsek (1) a § 462 Správneho súdneho poriadku.

${ }^{7}$ Pozri napríklad $§ 192$ - 193 Správneho súdneho poriadku. 
2018. Dôvodom je, že štatistické údaje za rok 2019 ešte nie sú kompletne spracované a dostupné.

Podl'a štatistických údajov Ministerstva spravodlivosti Slovenskej republiky ${ }^{8}$ bola priemerná dížka konania v rozhodovaní o správnych žalobách 20,97 mesiaca. V štatistikách poskytnutých Najvyšším súdom Slovenskej republiky nie je priamo uvedený údaj o dížke konania. $Z$ údajov v týchto štatistikách sa nachádzajúcich však možno ustálit' priemernú dížku konania na 8 mesiacov. ${ }^{9}$

Priemerná dížka konania na Ústavnom súde Slovenskej republiky bola za rok 2017 spolu 11,71 mesiaca. ${ }^{10}$ Táto dížka však zahŕňa všetky konania, pretože v predmetnom dokumente sa nenachádza štatistický údaj zahŕňajúci len prieskum vecí správneho súdnictva a kasačného súdnictva.

Priemernú dížku konaní pred Európskym súdom pre l'udské práva sa mi, žial', nepodarilo získat'. Podl'a oficiálnych údajov bolo k 31. 12. 2018 celkovo 56350 nevyriešených vecí, z ktorých 156 bolo zo Slovenskej republiky. ${ }^{11}$

Zosumarizovaním predmetných údajov je zrejmé, že proces ochrany je vel'mi dlhý. Ak by sme sčítali tieto údaje, dostaneme sa aj bez údajov z Európskeho súdu pre l’udské práva na číslo viac ako 42 mesiacov. Teda sme na čísle výrazným spôsobom prevyšujúcim tri roky.

K predlžovaniu práva prichádza aj v dôsledku aplikácie kasačného princípu. Orgány rozhodujúce na základe tohto princípu problém nevyriešia, ale vrátia ho na vyriešenie na orgán nižšieho stupňa. Na tomto orgáne musí opät' prebehnút' konanie, čo je spojené $\mathrm{s}$ d’alším časovým posunom.

Pomerne vysoká dížka konania pri prevažujúcej aplikácii kasačného princípu dostáva celý systém do pozícií, v ktorých sú subjekty v obrovskej neistote a svojím spôsobom aj neschopnosti domôct' sa svojich práv. V takto nastavenom systéme totiž nemožno vylúčit' situácie, a zo svojich skúseností z aplikačnej praxe viem, že k takýmto situáciám prichádza, v ktorých ochrana prichádza až príliš neskoro. Respektíve situácie, v ktorých napriek pozitívnemu rozhodnutiu nepríde $\mathrm{k}$ náprave vôbec. ${ }^{12}$

Po zrušení rozhodnutí, z ktorých vyplývali už vykonané práva, je potrebné riešit' d’alší problém. Je ním, ako naložit' s týmito dobromysel'ne nadobudnutými právami,

\footnotetext{
${ }^{8}$ Štatistická ročenka je uverejnená na internetovej stránke http://web.ac-mssr.sk/statisticka-rocenka-2018/, 8. 2. 2020.

${ }^{9}$ Je potrebné uviest', že toto číslo nie je presné. Vychádza zo skutočnosti, že v podla dostupných štatistík bolo v roku 2018 najviac vecí vybavených od 4 mesiacov do 1 roka. Navyše, tento údaj sa týka všetkých konaní pred Najvyšším súdom Slovenskej republiky v správnych veciach. Teda nielen vecí, kde správny súd rozhodoval $\mathrm{v}$ postavení kasačného súdu $\mathrm{v}$ procese kontroly rozhodnutí vydaných správnymi orgánmi v správnom konaní.

${ }^{10}$ Predmetný údaj je uverejnený v publikácii Ochrana ústavnosti a Ústavy Slovenskej republiky za rok 2017, publikovanej na https://www.ustavnysud.sk/documents/10182/991983/2_ochrana_FINAL.pdf/ b1be9ab2-ac3a-4543-9caf-b3a2ccff3091, 8. 2. 2020.

${ }^{11}$ Predmetný údaj je uverejnený v ročnej správe za rok 2018, publikovanej na https://www.echr.coe.int/ Documents/Annual_report_2018_ENG.pdf, 8.2.2020.

${ }^{12}$ Príkladom môže byt' zrušenie právoplatného a vykonatel’ného súhlasu na vyrúb dreviny v čase, v ktorom je už drevina vyrúbaná, alebo rozhodnutie, ktorým sa zruši už právoplatné a vykonatel'né rozhodnutie o vyčiarknutí znalca, ak je znalec už po uplynutí troch rokov nanovo zapísaný.
} 
ktoré však podl'a názoru vyšších autorít nemali byt' vôbec priznané. Navyše, na zrušené rozhodnutia mohli nadväzovat' d'alšie, ktoré s najväčšou pravdepodobnost'ou v čase zrušenia pôvodných rozhodnutí budú stále platné, právoplatné a vykonatel'né. ${ }^{13}$ Uvedené vytvára mnohé aplikačné problémy, ktoré, žial', súčasný poriadok vôbec nerieši.

\section{Uplatňovanie kasačného princípu a možnosti uplatnenia apelačného princípu}

S ohl'adom na všetko uvedené treba povedat', že kasačný princíp za súčasného nastavenia oddel'uje verejnú správu od súdnej moci. Umožňuje, aby si verejná správa sama napravila existujúce nedostatky. Rizikom apelačného princípu by bolo, keby sa verejná správa začala spoliehat' na súdy, že za ňu jej problémy vyriešia. Ak by sa teda prijala koncepcia apelačného princípu pri súdnom prieskume, či už v rámci správneho súdnictva alebo dokonca ústavného súdnictva, je na zváženie, či by neprišlo zo strany súdov k splynutiu vlastného výkonu súdnej moci a výkonu verejnej správy. Pre účastníkov konania by však výhoda apelačného princípu mohla byt' v tom, že by prišlo k skráteniu procesov. Súdy by zmenou rozhodnutí vyriešili priamo existujúce nedostatky. Navyše, kasačný princíp môže viest' aj ku komplikáciám za predpokladu, že súdy skonštatujú nezákonnost', ale z odôvodnenia súdnych rozhodnutí nebude pre adresátov týchto rozhodnutí jasné, akým smerom d'alej postupovat'. Takýto stav môže viest' $\mathrm{k}$ opakovaným žalobám.

Problém pri uplatňovaní kasačného princípu môže tiež nastat', ak adresáti rozhodnutí nebudú rešpektovat' názory vyššie postavených mocenských autorít. V takýchto prípadoch sa spravované subjekty doslova dostanú medzi dva mlynské kamene, z ktorých nemusí existovat' časovo prijatel'né východisko.

Vo vzt'ahu k uvedenému treba povedat', že už aj dnes máme konania, kde súdy by mali íst' nad rámec kontrolóra zákonnosti a preberajú niektoré úlohy v rámci verejnej správy. Príkladom sú žaloby v sociálnych veciach, v ktorých súd podl’a $§ 203$ odseku (2) Správneho súdneho poriadku nie je viazaný žalobnými bodmi a podl’a $§ 204$ Správneho súdneho poriadku môže súd doplnit’ dokazovanie vykonané orgánom verejnej správy.

Je pravdou, že aj v tomto druhu žalôb súd rozhoduje na základe kasačného princípu, ale s ohl'adom na stanovené kompetencie súdu v tomto konaní je už k apelačnému princípu len skutočne malý krôčik. Z uvedených ustanovení totiž vyplýva, že súd by mal preskúmat' rozhodnutie v celom rozsahu bez ohl'adu na skutočnosti, ktoré sú uvedené v žalobe. So zretel'om na možnost' doplnenia dokazovania aj bez návrhu možno predpokladat', že úmyslom zákonodarcu v týchto veciach bolo vložit' súdu kompetenciu rozhodovat' nie len o otázkach právnych, ale aj skutkových.

Prelomenie kasačného princípu je výrazné v § 193 Správneho súdneho poriadku, podl'a ktorého správny súd môže uložit' orgánu verejnej správy vykonat' povinnost'. Ked'že podl'a tohto ustanovenia by mal súd preskúmavat' fiktívne, teda v skutočnosti neexistujúce rozhodnutia, dostáva sa svojím spôsobom do roly orgánu rozhodujúceho

\footnotetext{
${ }^{13}$ Príkladom takejto situácie je zrušenie právoplatného a vykonatel'ného stavebného povolenia v čase, ked' je nehnutel'nost' postavená alebo dokonca aj skolaudovaná.
} 
o splnení povinnosti. Súd nemôže podl’a tohto ustanovenia posúdit’ neexistujúce rozhodnutia, a preto bude vychádzat' len z tvrdení žalobcu a žalovaného správneho orgánu. V tomto konaní sa tak v podstate dostáva z postavenia kontrolóra zákonnosti rozhodnutia do postavenia subjektu aktívne riešiaceho spor medzi dvomi subjektmi v konaní, ktorého výsledkom môže byt' uloženie povinnosti jednému zo subjektov.

Uvedené, podl'a môjho názoru, dokazuje, že eliminácia kasačného princípu prvkami charakteristickými skôr pre apelačný princíp nemá za následok zánik správneho súdnictva a jeho splynutie s verejnou správou. Domnievam sa však, že prechod k apelačnému princípu bude mat' zásadný vplyv na charakter výkonu tejto kontroly. Súdny prieskum tak bude nad’alej zvyšovat' svoj vplyv nielen na posudzovanie miery zákonnosti, ale aj pri posudzovaní skutkových otázok.

\section{Možnosti vývoja smerom do budúcnosti}

Súčasný systém nastavenia prostriedkom prieskumu rozhodnutí správnych orgánov je výsledkov viacerých faktorov spojených s tradíciou a vývojom. Napriek tomu sa domnievam, že z dlhodobého hl'adiska je neudržatel'ný. Ak sa totiž obyvatelia nedostanú k svojim právam riadne a včas, budú hl'adat' iné, často aj neprávne možnosti, ako si svoj ciel' zabezpečit'. Za predpokladu, že budú osoby čakat' na ochranu niektorých svojich subjektívnych práv doslova niekol'ko rokov, zo strany týchto subjektov môže príst' k logickej nespokojnosti spojenej s nedôverou v systém a štát. Navyše si treba uvedomit', že čast' konaní môže byt' vedená a predlžovaná zo strany niektorých účastníkov konania aj preto, aby sa zabránilo inému účastníkovi dostat’ sa k svojmu právu v rozumnom čase. Som preto presvedčený, že do budúcna bude potrebné, aby sa celý systém prehodnotil a hl'adali sa spôsoby rýchlejšieho riešenia.

Jednou z ciest, ktorou by sme sa mohli ubrat', je redukcia jednotlivých prostriedkov nápravy. $\mathrm{K}$ tejto redukcii možno pristúpit’ aj v správnom konaní, ale aj v rámci prostriedkov súdnej kontroly.

V teórii existujú aj dnes práce, ktoré sa venujú eliminácii možností podávania odvolania a možnosti prelomenia princípu dvojstupňovosti správneho konania v niektorých druhoch konaní. ${ }^{14}$ Ja som v tomto smere už v roku 2008 na Brnianskych právnických dňoch vyslovil názor, podl'a ktorého by konania, kde v prvom a druhom stupni rozhoduje vedúci ústredného orgánu štátnej správy, mohli prebiehat' len v jednom stupni. Zaujímavý v tomto smere bol poznatok prezentovaný Wojciechom Piątekom na tohtoročnom Bratislavskom právnickom fóre, podl’a ktorého sú v Pol'sku názory podporujúce prejst' na jednostupňové správne konanie v správnych konaniach, v ktorých neprichádza k devolutívnemu účinku. $\mathrm{S}$ takouto tézou by bolo dobré pracovat' aj pri d'alších prípravách novej právnej úpravy v Slovenskej republike.

Je tiež otázne, či sú potrebné dvojstupňové správne konania v druhoch konaní, kde rozhodujú orgány s dostatočnou mierou nezávislosti a erudície. V tejto súvislosti by som

${ }^{14}$ Pozri napríklad DŽAČKOVÁ, M. Princip právnej istoty pri preskúmavani správnych rozhodnutí. Dizertačná práca, 2019. 
mohol spomenút' napríklad správne konania pred Radou pre vysielanie a retransmisiu, ktoré sú vedené v jednom stupni.

Možnosti redukcie vidím aj v rámci súdneho prieskumu. V roku 2012 som vystúpil na konferencii Pôsobnost' a organizácia správneho súdnictva v Slovenskej republike $\mathrm{s}$ príspevkom Jeden súd pre správne súdnictvo, $\mathrm{v}$ rámci ktorého som riešil, či by nebolo efektívnejšie vytvorit’ jeden silný správny súd, v ktorom by sa pri možnej silnej obsadenosti a špecializácii prejednávali veci patriace do správneho súdnictva $\mathrm{v}$ jednej inštancii bez možností riadnych a mimoriadnych opravných prostriedkov.

Je na posúdenie, či je v súčasnosti opodstatnené mat' jednostupňové správne súdnictvo s možnost'ou podania kasačnej st'ažnosti v takomto širokom rozsahu. Najmä v konaniach, kde kasačný súd s ohl'adom na čas a aplikáciu kasačného princípu síce zruší rozhodnutie správneho súdu pre nezákonnost', ale toto rozhodnutie príde v čase, ked' kasačný súd už nebude $\mathrm{v}$ dôsledku nových rozhodnutí vydaných na základe právneho názoru krajského súdu mat' možnost' ovplyvnit' existujúci stav. ${ }^{15}$

Treba povedat', že aj súčasný systém môže mat' svoje opodstatnenie. To však len za predpokladu, že v rámci tohto systému bude taká minimálna chybovost', že súdna moc bude svojimi rozhodnutiami zasahovat' do existujúceho právneho stavu len minimálne. V takomto prípade by orgány súdnej kontroly mohli fungovat' na kasačnom princípe a ani pridlhé lehoty na rozhodnutie by nemuseli negatívne ovplyvnit' efektívne fungovanie celého systému.

Je však otázne, či táto úvaha v súčasných podmienkach Slovenskej republiky je uskutočnitel'ná. Z údajov štatistickej ročenky Ministerstva spravodlivosti Slovenskej republiky za rok 2018 vyplýva, že správne súdy v tomto roku vybavili 4417 vecí, pričom zrušili napadnuté rozhodnutia v 41,41 \% konaní. Tento údaj nehovorí len o vel'kej chybovosti orgánov verejnej správy, ale aj obrovských zásahoch do právnej istoty zo strany krajských súdov.

Domnievam sa, že v súčasnosti sa nám uvedené vo vnútroštátnom súdnictve podarilo na úrovni Ústavného súdu Slovenskej republiky. Z výskumu, ktorý som prezentoval na konferencii Bratislavské rozpravy o správnom práve 2018, vyplynulo, že v konaniach Ústavného súdu Slovenskej republiky vedených pre namietané porušenie článku 46 Ústavy bolo v rokoch 2011 - 2017 rozhodnuté 95207 vecí, pričom porušenie bolo skonštatované len v 596 veciach. V percentuálnom vyjadrení je to $0,626 \%$ prípadov. V tomto smere treba povedat', že v posudzovanom období bol zvýšený nápad na Ústavný súd Slovenskej republiky. Bude preto zaujímavé sledovat', ako sa bude situácia vyvíjat' v budúcnosti.

\section{Záver}

Pri písaní tejto prednášky mám pocit, že nás čaká vo výskume ešte vel'mi vel'a práce. Hladanie optimálnych riešení je dlhodobým procesom, ktorý pravdepodobne nikdy

\footnotetext{
${ }^{15}$ Ak napríklad na základe rozsudku krajského súdu v postavení správneho súdu príde k zrušeniu právoplatného rozhodnutia Ministerstva spravodlivosti Slovenskej republiky o vyčiarknutí mediátora z registra mediátrov, Ministerstvo spravodlivosti Slovenskej republiky je povinné konat’ na základe právneho názoru vysloveného v tomto rozsudku a vydat' nové rozhodnutie. Ak by kasačný súd na základe kasačnej st’ažnosti zrušil rozsudok správneho súdu, uvedené by nemalo dosah na nové rozhodnutie vydané správnym orgánom v intenciách zrušeného právneho názoru kasačného súdu.
} 
nemá koniec. V tomto smere si často si spomínam na slová jedného môjho učitel’a, ktorý mi v neformálnom rozhovore povedal, že v humanitných vedách môžeme daný problém len kvalitatívne posunút', ale nevieme nájst' ideálne riešenie na úplne vyriešenie tohto problému. $^{16}$

Pri d’alšom vývoji som toho názoru, že by sme mali postupovat' redukciou prostriedkov nápravy. Zvážit', kde v súčasnosti by sme vedeli v správnom konaní zasiahnut' do zásady dvojstupňovosti konania. Samozrejme, bude potrebné pracovat' aj s inštitútmi, ktoré konanie zrýchlia. Príkladom môže byt' posilnenie zásady koncentrácie na úkor zásady jednotnosti konania.

Revíziou budú musiet' prejst' aj mimoriadne opravné prostriedky. Osobitne bude potrebné preskúmat', či neobmedzit' rozsah rozhodnutí, ktoré môžu byt' preskúmané v konaní o preskúmanie rozhodnutia mimo odvolacieho konania. Tento inštitút budovaný tiež na kasačnom princípe môže výrazným spôsobom zasahovat' do právnej istoty. Nie je pritom nijakým spôsobom limitovaný počet podnetov, ktoré je možné podat' dokonca aj proti jednému rozhodnutiu.

Rovnako bude potrebné zadefinovat', v ktorých druhoch konaní by stačilo jednostupňové správne súdnictvo bez možnosti kasačnej st’ažnosti. V týchto prípadoch však bude potrebné riešit' aj otázky príslušnosti, pretože aj v súdnom systéme je vel'mi dôležité, aby v poslednej inštancii rozhodoval jeden súd s pôsobnost'ou pre celé územie Slovenskej republiky. Ak by totiž konkrétny druh vecí končil na všetkých ôsmich krajských súdoch, mohlo by stat', že tieto súdy si pôjdu vlastnou cestou s odlišnou aplikáciou, čo by malo tiež nesmierne negatívny vplyv na princíp právnej istoty.

V rámci skúmania je potrebné sa vyriešit' aj organizačné otázky. Bude treba otvorit' diskusiu o opodstatnenosti ôsmich správnych súdov v správnom súdnictve. Tieto otázky sú tiež predmetom môjho výskumu, avšak prevyšujú tému dnešnej prednášky.

V neposlednom rade bude treba otvorit' aj otázku, či nad'alej správne súdnictvo bude fungovat' na kasačnom princípe, alebo či bude prichádzat' k posilňovaniu apelačných prvkov. V tomto smere bude dôležitá aj súdna iniciatíva. Ak súdy pristúpia k posudzovaniu rezervovane a obmedzia sa len na základnú kontrolu zákonnosti, zrejme súčasný systém vydrží. Za predpokladu zvyšovania iniciatívy zo strany súdov napríklad definovaním právne neurčitých pojmov, dávaním návodov správnym orgánom týkajúcich sa postupov pri vykonávaní dokazovania, uvádzaním, akým spôsobom riešit' legislatívne medzery, sa hranica medzi verejnou správou a výkonom správneho súdnictva bude stierat'. Jedného dňa sa tak môže stat', že súdny prieskum postavený na kasačnom princípe upravenom v § 191 Správneho súdneho poriadku bude prekonaný a spoločenský tlak donúti legislatívu k úplnému ústupu od kasačného princípu k princípu apelačnému.

Treba povedat', že aj v Európe máme štáty, v ktorých po jednostupňovom správnom konaní prichádza priamo súdna kontrola. Pri takomto modeli by boli opodstatnené silné apelačné prvky v správnom súdnictve. Domnievam sa však, že v spoločnosti treba rešpektovat' aj dlhodobý vývoj a právnu tradíciu, preto takúto cestu v našich právnych podmienkach by som neodporúčal.

\footnotetext{
${ }^{16} \mathrm{~S}$ ohl'adom na neformálny rozhovor, verím, že som parafrázoval podstatu jeho myšlienky správne.
} 
Pri rozhodovaní o aplikácii kasačného princípu alebo apelačného princípu je tiež vel'mi dôležité zvažovat' základné zásady správneho konania a princípy právneho štátu. Táto úloha stojí najmä pred odvolacími orgánmi, ktoré majú možnost' napadnuté nesprávne a nezákonné rozhodnutie bud' napravit', alebo zrušit', a vec vrátit' na d'alšie konanie. Z čisto psychologického hl'adiska je, samozrejm,e jednoduchšie pre odvolacie orgány použitie kasačného princípu v porovnaní s apelačným princípom. Kritériom pri výbere možnosti, akou sa vydat' v rámci právnej praxe, by však mali byt' rýchlost' konania a hospodárnost' konania. Teda pri výbere, či zmenit' prvostupňové, alebo ho zrušit' a vec vrátit' na d’alšie konanie, by sa malo posudzovat', výberom ktorej možnosti príde k rýchlejšiemu a ekonomicky menej náročnému odstráneniu nezákonnosti alebo nesprávnosti rozhodnutia správneho orgánu.

Obdobnú situáciu musia riešit’ súdy pri aplikácii už spomínaného § 193 Správneho súdneho poriadku. Tiež majú na výber, či budú postupovat' podl'a všeobecného $§ 191$ odseku (1) Správneho súdneho poriadku, alebo $§ 193$ umožňujúceho preskúmat’ aj fiktívne rozhodnutie. Domnievam sa, že aj pri odpovedi na túto otázku by mala prevážit' zásada rýchlosti konania a hospodárnosti konania tak, aby sa účastníci konania dostali čo najrýchlejšie k definitívnemu zákonnému výsledku.

K d’alším úlohám patrí aj presvedčenie spoločnosti a politických elít o potrebe riešenia nami nastolených problémov a vhodnosti našich riešení. Bez podpory a akceptácie verejnosti práca právnej vedy nemôže fungovat' a môže sa stat', že publikované výsledky našej práce budú len „šuplíkovou literatúrou“ odkázanou len na možný historický výskum v budúcnosti.

Na úplný záver sa vrátim na začiatok a pripomeniem, že aplikácia kasačného princípu v spojení s vel'kou dížkou konaní a možnost'ou zasiahnutia do už právoplatného stavu je vel'mi nebezpečnou kombináciou. Nastolenie právnej istoty je pre právne vzt'ahy vel'mi dôležité a ak vytvárame mechanizmy, ktorými môžeme neustále otvárat' právoplatné rozhodnutia, nutne nastáva stav neistoty a nedôvery. Navyše, ak nadriadená autorita nedokáže priamo problém vyriešit'.

Pocit osoby, že vyhrala na nadriadenom súde a nič sa aj tak nezmenilo, je vel'mi nebezpečný, vedúci k obrovskej nedôvere $\mathrm{v}$ celý systém a štát. Je preto potrebné aj v rámci právnej vedy neustále hl'adat' riešenia, ktoré systém budú procesne zjednodušovat', ale obsahovo neustále skvalitňovat'. Je to ako nosenie stále horiacej pochodne, ktorú sme prebrali od našich predchodcov a ktorú mi raz odovzdáme našim nasledovníkom.

Dámy a páni, d’akujem za pozornost'.

\section{Literatúra}

1. DŽAČKOVÁ, M. Princíp právnej istoty pri preskúmavani správnych rozhodnutí. Dizertačná práca, 2019

2. PEKÁR, B. Kontrola vo verejnej správe v kontexte Európskeho správneho súdnictva. Bratislava : Univerzita Komenského v Bratislave, Právnická fakulta, 2011

3. SOBIHARD, J. Správny poriadok. Komentár. Bratislava : Iura Edition, 2011 